\title{
Trading Citizenship, Human Capital and the European Union
}

\author{
David Owen
}

In 2003 the brilliant Kenyan steeplechaser Stephen Cherono switched his allegiance to Qatar and took the name Saif Saaeed Shaheen. Under this name he has set a world record and won a number of global medals for Qatar which, alongside Bahrain, pioneered the explicit policy of recruiting athletes who have no prior connection to the state but whose human capital would contribute to its self-determined goals. Such practices are not entirely new - for example, the Australian and New Zealand national rugby teams (union and league) have maintained their standing in world rugby in part by actively recruiting young talent from the Pacific nations - Fiji, Papua New Guinea, Cook Islands, Tonga and especially Samoa - to the detriment of the national teams of those states. But, as with the case of Malta selling its citizenship for $€ 650,000$, the policies adopted by Qatar and Bahrain are blatant in making explicit what was merely implicit in the rather widespread policies of other states, namely, the trading of access to citizenship for forms of capital (economic, cultural, political, etc.) held by individuals which the state deems valuable to acquire. Whether it is inducements to foreign millionaires (where other EU countries are playing catch up with long-standing UK policies) or to skilled workers in medical, finance or IT sectors, the immigration policies of states are perennially engaged in the practice of identifying valued forms of capital and facilitating the inward flow of such capital. The emigration policies of states exhibit similar patterns whether in terms of the deliberate creation of human capital for export markets (e.g., Indian medics and Filipino nurses) and/or the maintenance of thick links to diasporic communities to support trade, knowledge transfers, remittance flows and the recruitment of sporting talent. The state as a self-determining agent has a clear and well-established interest in structuring 'access to citizenship' in ways that support its goals, whether these goals concern economic development, health and social welfare, cultural standing or sporting glory. The legitimacy of the ways in which it pursues these goals is however another question. 
For the states that compose the EU, we can distinguish three dimensions of democratic legitimacy that address, respectively, the composition of the demos of the state, associative obligations between member states and democratic obligations to non-members. Let's take them in turn.

If we focus on the composition of the demos, then it is important to acknowledge the difference of selling citizenship in a global market with schemes that, as Ayelet Shachar rightly notes, simply facilitate residence for selected types of highly valued persons and hence the acquisition of citizenship via residence-based naturalisation procedures. As Bauböck, Dzankic and Ochoa all stress, the 'golden residence permit' schemes (whatever other faults they may have) require a multi-year period of residence within, and hence subjection to, the authority of the state in question prior to, and as a condition of, the acquisition of citizenship. Such required residence grounds the claim to political equality that is given expression in access to membership of the demos.

Turning to the second dimension of democratic legitimacy of EU states, the associative obligations of member states, we can note that the explicit Treaty-based commitment to solidarity among these states has a specific implication for their democratic composition in that, normatively, it constrains states to treat their own citizenship (over which the EU has no - or via the Court of Justice of the European Union, very limited - competence) as integral to the democratic character of the EU. In this respect, Bauböck is surely right to highlight the point that selling national citizenship (and hence also EU citizenship) is incompatible with the associative obligations of member states as it admits persons to EU citizenship in all member states who do not have any genuine connection to any of these states. However, the scope of such obligations is not merely tied to such blatant examples of the commodification of citizenship but extends to the wider range of practices that are brought into focus by such extreme examples insofar as these undermine political equality with the EU by, for example, importing class and status differentials into access to citizenship.

The third dimension of democratic legitimacy for EU member states concerns those non-members whose morally significant interests are affected by the citizenship policies of these states. The requirement here is that these interests are impartially considered within the policy-making process. In contrast to Bauböck's distinction between democracy and global justice, I want to stress that this third dimension links the two and ties the concerns acutely raised by Barbulescu and, in more fatalistic mode, by Spiro directly to democratic legitimacy. As Barbulescu notes, the neo-liberalisation of citizenship that is expressed in practices of trading citizenship entails that the 
policy-making process does not give impartial consideration to all those whose morally significant interests are affected by these citizenship policies. Rather, the duty of justification owed to those affected is abrogated through a deliberate practice of partiality in which the rich and those who possess talents that are highly valued by the states in question are provided with unequal access to residence and hence to citizenship. Practices that support the emergence of transnational class and status stratification in which mobility rights become radically unequally distributed are not compatible with the democratic legitimacy of states or of the EU.

Oddly then we have reason to be grateful to states such as Qatar and Malta whose policies, in pushing to the neoliberal extreme, help bring into focus a wider range of policies that are hollowing out democratic citizenship from within.

Open Access This chapter is licensed under the terms of the Creative Commons Attribution 4.0 International License (http://creativecommons.org/licenses/by/4.0/), which permits use, sharing, adaptation, distribution and reproduction in any medium or format, as long as you give appropriate credit to the original author(s) and the source, provide a link to the Creative Commons license and indicate if changes were made.

The images or other third party material in this chapter are included in the chapter's Creative Commons license, unless indicated otherwise in a credit line to the material. If material is not included in the chapter's Creative Commons license and your intended use is not permitted by statutory regulation or exceeds the permitted use, you will need to obtain permission directly from the copyright holder.

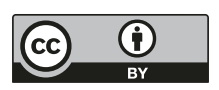

